Rev. Emery de Gaál University of St. Mary of the Lake, Mundelein Seminary, Chicago

\title{
Anselm of Canterbury and the Third Reich: Gottlieb Söhngen on Upholding the Humanum Amid the Inhumane
}

Gottlieb Söhngen (1892-1971) is a figure of no small significance: he directed both Joseph Ratzinger's (now Pope Emeritus Benedict XVI) dissertation and habilitation, and his writings on Anselm of Canterbury's theological contributions illustrate the struggles of a then still nascent theological discipline: fundamental theology. Söhngen's explorations occur within the context of National Socialist rule, while he teaches theology at Akademie Braunsberg in the eponymous city located in East Prussia (1937-45) during the dark years of the Third Reich. This investigation shows how very much Söhngen does justice to both Anselm's oeuvre and the Roman Catholic statement, while nevertheless introducing pointers to pre-Christian, Germanic notions in order to flatter the Nazi rulers, but more importantly to underscore how pagan concepts ultimately indirectly prepare the ground for the implantation of the Gospel.

Key words: Anselm of Canterbury, Gottlieb Söhngen, Joseph Ratzinger, Pope Emeritus Benedict XVI, Braunsberg Akademie/Braniewo, national socialism.

Throughout history the humanum has been and is under attack. Despite the hardship and suffering these contestations cause, over the long term such threats invigorate the positive and creative forces of culture. In the course of history these threats alter their guises. In the wake of Enlightenment and the attendant remarkable scientific discoveries as well as the therefrom resulting industrial revolution, something novel and unparalleled stepped onto the stage of history: man-made ideologies. In contrast to philosophy or literature, which thrive by allowing the dynamics of life to speak a priori to thinkers, by definition an ideology beguilingly offers a self-contained, exhaustive 
Dogmatic Theology

explanation of history, humankind, and the individual human person to which reality need conform! By attempting a complete description of the meaning of life without a metaphysical eradication, ideologies invariably become totalitarian and, thereby, deeply inhumane. In the twentieth century, called "the wolfhound century" by the JewishRussian poet Osip Mandelstam (1891-1938), two ideologies-communism and national socialism—fatefully asserted their ugly grimaces.

\section{Gottlieb Söhngen}

The German Catholic priest and theologian Gottlieb Söhngen (18921971) was confronted with the task of preserving the humanum in general and the integrity of the Christian creed specifically vis-à-vis National Socialism during the Third Reich (1933-45) as a professor teaching at the state-run Braunsberg Akademie in East Prussia. He had been ordained a priest for the Archdiocese of Cologne. ${ }^{1}$

Söhngen is of no little interest for the history of theology as he stands intellectually at the border between two different methods of communicating the one and same Catholic faith, the transition from a highly intellectual, though somewhat rigid Neo-Scholasticism to a personalist shift in Catholic theology, which will manifest itself especially during and after the Second Vatican Council (1962-65). Söhngen becomes quite influential by being the Doktorvater and habilitation director of a most prominent theologian, Joseph Ratzinger, the future Pope Benedict XVI. Under Söhngen's aegis Ratzinger wrote the prize-winning dissertation Haus und Volk Gottes bei Augustinus (House and People of God with Augustine) in 1951. ${ }^{2}$ Ratzinger uncovers afresh the notion of the Church as "the People of God." This Augustinian term will figure prominently during Vatican II. ${ }^{3}$ In 1955 , Ratzinger penned his terminal paper and the habilitation on St. Bonaventure's understanding of history. ${ }^{4}$ Famously, this will permit the peritus Ratzinger to advise the hugely influential Archbishop of Cologne Cardinal Josef Frings at the Second Vatican Council to reject the original schema on revelation in

$1 \quad$ Wolfgang Klausnitzer, "Gottlieb Söhngen," in Biographisch-Bibliographisches Kirchenlexikon (BBKL), Band 21 (Nordhausen: Bautz, 2003), rubrics 1446-1454.

2 2 Joseph Ratzinger, Volk und Haus Gottes in Augustins Lehre von der Kirche: die Dissertation und weitere Studien zu Augustinus und zur Theologie der Kirchenväter, in Joseph Ratzinger, Joseph Ratzinger Gesammelte Schriften (JRGS), Bd. 1 (Freiburg i. Br.: Herder, 2011).

See Lumen Gentium, especially chapter II, 9-18.

Joseph Ratzinger, The Theology of History in St. Bonaventure, trans. Zachary Hayes OFM (Chicago: Franciscan Herald Press, 1989). 
1962 and suggest a more dynamic understanding of revelation instead. ${ }^{5}$ This perspective no longer considers revelation as the communication of timeless propositions or postulates to be believed, but as encounter with the Lord, mediated by Scripture and Tradition (Dei Verbum 2).

As a priest of the Archdiocese of Cologne, Söhngen had probably played a decisive role in Ratzinger's appointment as professor to the prestigious Chair of Fundamental Theology at Bonn University. He may also have been instrumental in Ratzinger's acquaintance with the Cologne Cardinal Frings.

Söhngen had studied philosophy and theology with an emphasis on the former in Bonn and Munich. In 1915, he earned a doctoral degree on Kant's epistemology with a dissertation titled Über analytische und synthetische Urteile. Eine historisch-kritische Untersuchung zur Logik des Urteils (On analytical and synthetical Judgments. A historicalcritical Examination regarding the Logic of Judgment). ${ }^{6}$ The historian of philosophy Clemens Baeumker (1852-1924), who had applied the historical-critical method to medieval texts, and Joseph Geyser (18691948) influenced Söhngen by teaching him an enlightened form of Neo-Scholasticism. Söhngen was interested in Kant, Edmund Husserl (1859-1938), Husserl's student Max Scheler (1874-1928), and Nikolai Hartmann (1882-1950). While director of the Albertus-Magnus-Akademie in Cologne, Söhngen completed his major philosophical text Sein und Gegenstand. Das scholastische Axiom Ens et Verum convertuntur als Fundament metaphysischer und theologischer Spekulation (Being and Object. The scholastic Axiom Ens et Verum convertuntur as Foundation for metaphysical and theological Reflection, 1930), ${ }^{7}$ thereby earning a doctoral degree in theology from Tübingen University. He wrote his habilitation in the area of fundamental theology, titled Teilhabe am göttlichen Wissen (Participation in divine Knowledge, 1931) at Bonn University under the direction of the fundamental theologian Arnold Rademacher (1873-1939). ${ }^{8}$

While teaching as private docent in Cologne (1931-37), Söhngen became acquainted with the Catholic ecumenist and member of the

5 Joseph Ratzinger, Milestones. Memoirs 1927-1977 (San Francisco: Ignatius, 1998), $46-120$.

$6 \quad$ Gottlieb Söhngen, Über analytische und synthetische Urteile. Eine historischkritische Untersuchung zur Logik des Urteils (Köln: J. Bachem, 1915).

$7 \quad$ Gottlieb Söhngen, Sein und Gegenstand. Das scholastische Axiom Ens et Verum convertuntur als Fundament metaphysischer und theologischer Spekulation (Münster: Aschendorff, 1930).

8 Gottlieb Söhngen, Teilhabe am göttlichen Wissen (Habilitation, University of Bonn, 1931) unpublished. 
Dogmatic Theology

Cologne cathedral chapter Robert Grosche (1881-1967), the founding editor of Catholica, a journal devoted to ecumenical studies. Söhngen will become the journal's editor in 1958. He participates in the 1930's and 40's in the Protestant-Catholic dialogue on natural theology and the analogia entis, which involves namely Karl Barth, Emil Brunner, and Erich Przywara. He is also involved in the conversation on the theology of mystery with the noted Benedictine liturgiologist Odo Casel (1886-1948).

In 1937, Söhngen is appointed professor of theology at the government-run Akademie Braunsberg in East Prussia. He will occupy this position until his flight from the advancing Soviet forces in 1945 at the end of World War II. From 1947 until 1958 he teaches fundamental theology at Munich University, where Joseph Ratzinger will be his stellar student. While in Bavaria, he joins the Jäger-Stählin ecumenical group, initiated by the then-Archbishop of Paderborn Lorenz Jäger and the Protestant bishop of Oldenburg, Wilhelm Stählin, which will contribute indirectly to the ecumenical document Unitatis Redintegratio at Vatican II.

The name Söhngen represents a basic shift in accent in theological thought that is well captured in the change of the title of an important discipline of Catholic theology — namely, of apologetics to fundamental theology. While the former tended to be merely defensive and restorative, the latter establishes the common search of all of humankind for a personal meaning that only the Second Person of the Blessed Trinity can ultimately grant. A good summary of Söhngen's vision is captured in his essay as emeritus "Die Weisheit der Theologie durch den Weg der Wissenschaft" (The Wisdom of Theology through the Path of Science) in the first volume of the dictionary Mysterium Salutis. ${ }^{9}$ In a sense, the work is a good synopsis of his unpublished defense lecture presented during his 1932 habilitation entitled Die katholische Theologie als Wissenschaft und Weisheit (Catholic Theology as Science and Wisdom). ${ }^{10}$

Söhngen participated in important theological discussions. He dialogued with noted contemporary Protestant theologians just as easily as with the ancients: Plato and Aristotle, Kant and Hegel, Augustine, Anselm of Canterbury, Thomas Aquinas and Bonaventure.

\footnotetext{
9 Gottlieb Söhngen, "Die Weisheit der Theologie durch den Weg der Wissenschaft," Mysterium Salutis, Bd. I (Einsiedeln: Benzinger, 1965), 907-978.

10 Gottlieb Söhngen, Die katholische Theologie als Wissenschaft und Weisheit (Paderborn: Winfriedbund, 1932).
} 
Söhngen had contributed five titles to Anselm research: the two articles "The Unity of Theology in Anselm's Proslogion"11 and "The Ancient-Christian Science and Wisdom in Anselm's New, Germanic Form of Thinking," 12 as well as three encyclopedia entries "Credo, ut intelligam," "Fides quaerens intellectum," and "The Ontological Proof of God's Existence" in the German Catholic dictionary Lexikon für Theologie und Kirche, second edition, edited by Josef Höfer and Karl Rahner. ${ }^{13}$

The city of Braunsberg, now the Polish city of Braniewo, and onetime fortress of the Teutonic Order in East Prussia, is historically the center of the Catholic enclave Ermland (Warmia), in an otherwise overwhelmingly Protestant region of the former Kingdom of Prussia. In an effort to regain a foothold, the Catholic Prince-Bishop of the Bishopric of Warmia, Stanislaw Hosius (1504-1579), had founded the Lyzeum Hosianum in 1565. It served as a high school, academy, and theologate for seminarians until 1945. Since 1811 the Prussian government operated it. Thus, the Akademie Braunsberg, as it had come to be known in the nineteenth century, was under National Socialist control (since 1936) when Söhngen taught there as professor of theology from 1937 until 1945. One of its graduates was Konrad Zuse, the German inventor of the computer. ${ }^{14}$

In this ambience of political tutelage in all matters, including theology, Söhngen delivered two papers on Anselm of Canterbury. While "Die Einheit der Theologie in Anselm's Proslogion" (The Unity of Theology in Anselm's Proslogion) delivered in 1938 is still apolitical in tenor, the second lecture held in 1940 had to justify discussing the Christian monk and theologian Anselm at an institution controlled by a National Socialist academic administration that believed in the superiority of the Arian race and at best in a non-Christian, Germanic religion, but certainly not in a Catholic form of Christianity.

11 Gottlieb Söhngen, "Die Einheit der Theologie in Anselms Proslogion," in Die Einheit der Theologie (Munich: Karl Zink, 1952), 24-62.

12 Gottlieb Söhngen, "Die antik-christliche Wissenschaft und Weisheit in Anselms neuer, germanischer Denkform," Wissenschaft und Weisheit 8 (1941): 109-119.

13 Gottlieb Söhngen, "Credo ut intelligam," in Lexikon für Theologie und Kirche, Bd. 3, 2nd ed., (Freiburg i. Br.: Herder, 1959), 89-91; Ibid, "Fides quaerens intellectum," in Lexikon für Theologie und Kirche, 2nd ed. Bd. 4 (Freiburg i. Br.: Herder, 1960), 119f; Ibid, "Ontologischer Gottesbeweis," in Lexikonfür Theologie und Kirche, 2nd ed., Bd. 7 (Freiburg i. Br.: Herder, 1962), $1160 f$.

14 Manfred Clauss, "Die Theologische Hochschule Braunsberg," in Udo Arnold, ed., Preussen als Hochschullandschaft im 19./20. Jahrhundert, (Lüneburg: Norddeutsches Kulturwerk, 1992), 23-42. 
Dogmatic Theology

\section{National Socialism and Religion}

National Socialism was quasi- or pseudo-religious in nature. Officially it did not deny the existence of the numinous but realiter its leaders lived as etsi Deus non daretur. Hitler's Reich Minister for Church Affairs, Hanns Kerrl (1887-1941), had advocated "positive Christianity," rejecting in true Marcionite fashion the Old Testament and depicting Jesus as an Aryan. National Socialism tried to control all religious institutions. Nazi ideology did not allow for the existence of anything apart from this worldview. In logical continuity with Social Darwinism, it postulated that everything must be subordinated to a "Germanic" way of living. Thus, Nordic superiority should manifest itself. The Reich Minister for Propaganda, Joseph Goebbels, claimed that there is "an insoluble opposition between the Christian and a heroic-German world view." 15 The chief Nazi ideologue, Alfred Rosenberg (1892-1946) argued that all "foreign" forms of Christianity prior to the ascendance of the Germanic race around $800 \mathrm{AD}$ must be exterminated. This necessitates removal of all Bibles and the cessation of its publication. Belief in Jesus Christ as the Son of God and the Apostles' Creed are not part of pure, Teutonic "Positive Christianity." Only a copy of Mein Kampf may lie on the altars. A sword should replace the cross. ${ }^{16}$ Despite the concordat signed between the Holy See and the Reich in 1933, the Nazi government gradually refunctioned church property that was not strictly religious. Thousands of Catholic priests were incarcerated. Hundreds of monasteries were seized, and religious newspapers and journals were censored or banned. ${ }^{17}$

As mentioned, Söhngen was professor at Braunsberg Akademie, which lay in the then-German province of East Prussia. Its ruler was the Nazi Gauleiter Erich Koch (1896-1986). In a speech Koch identified Hitler as "the new Martin Luther," who introduces a new form of Christianity, wholly divorcing this new religion from Jesus Christ and Scripture. ${ }^{18}$ To Koch's mind Hitler liberates Germans from the oppressive and humiliating yoke of living under the religious precepts of

$15 \quad$ Martin Korschoke, Geschichte der bekennenden Kirche, allein das Wort hat's getan (Göttingen: Vandenhoeck \& Ruprecht, 1976), 495.

16 Richard James Overy, The Dictators: Hitler's Germany and Stalin's Russia (New York: W. W. Norton, 2004), 283f; John S. Conway, The Nazi Persecution of the Churches 1933-1945, (Vancouver: Regent College Publishing, 2001), 232 -257.

17 See Karl-Joseph Hummel, Michael Kiener, Christof Morrisey, Catholics and Third Reich: Controversies and Debates (Paderborn: Schöningh/Brill, 2018).

18 Richard Steigmann-Gall, The Holy Reich (Cambridge: Cambridge University, 2003), 120. 
an inferior person and race. Nota bene: the politician Koch also made this statement in his role as the duly elected President (Präses) of the Lutheran Provincial Church Synod of East Prussia. ${ }^{19}$ Little wonder, in February 1940 Karl Barth accused German Lutherans of sacrificing biblical teaching and thus the essence of Christianity for the sake of Nazi state ideology. ${ }^{20}$

\section{Söhngen and his Defense of Anselm of Canterbury}

Tellingly, the title of Söhngen's second public lecture at Braunsberg Akademie is "The Ancient-Christian Science and Wisdom in Anselm's New, Germanic Form of Thinking." It was part of a series titled "Trailblazers of the Germanic Spirit in Medieval Scholarship" held during the first trimester of $1940 .{ }^{21}$ In all probability the National Socialism Gauleiter Erich Koch attended the lectures. ${ }^{22}$ It was a major academic, political, and social event in East Prussia. While the Second World War had begun in the West, war with Russia would begin only in 1941 .

In the opening sentences Söhngen reminds his audience that the Greeks produced culture and scholarship, as the great German and East Prussian philosopher Immanuel Kant (1724-1804) had noted in the preface to his Critique of Pure Reason. Directed against the materialistic pragmatism of National Socialism, Söhngen says that the cultured men of ancient Greece did not strive for knowledge in order to improve materially their lives, but because "they sensed that in pure investigation the nobility of a free person finds expression. ... [This] ... enthusiasm for pure scholarship is the highest and most free, absolutely divine form of living for the human being." 23 Metaphysics' ultimate intention is to seek wisdom for its own sake by way of the sciences. As a side benefit, so to speak, metaphysics seeks to advance towards the ultimate, primordial ground of being so that human beings can properly form their lives. This is realized by pursuing scholarship in a disciplined manner. In this context, Söhngen quotes Augustine:

19 Ralf Meindl, Ostpreussens Gauleiter: Erich Koch - Eine politische Biographie, (Osnabrück: Fibre, 2007).

Karl Barth, Eine Schweizer Stimme, 1938-1945, (Zürich: Theologischer Verlag, 1945), 122.

Söhngen, "Die antik-christliche Wissenschaft und Weisheit in Anselms neuer, germanischer Denkform," 14: "Bahnbrecher germanischen Geistes in der mittelalterlichen Wissenschaft." germanischer Denkform," 14, fn 1. 
"Tendimus per scientiam ad sapientiam" - we strive through scholarship for wisdom. ${ }^{24}$ It was a bit cheeky for Söhngen to quote a Latin line, as on the whole Nazis lacked higher education and, therefore, did not understand the language of Horace and Virgil; this certainly included Koch.

Söhngen reminds his audience: "It is within the social and intellectual space of the Church that the Germanic tribes encounter Greek culture and scholarship." ${ }^{25}$ In the encounter of the Christian gospel with Greek culture Christianity proved victorious and "captured" Greek erudition. The victorious faith found its erudite incarnate expression in Greek thought. The free spirit of Greece, trained in discipline and ascetism, meets a truth that is truth for its own sake or purpose - and Greek philosophy had pursued this wholly non-utilitarian, sublime goal ever since Parmenides and Heraclitus. He reminds his German audience of the classic German poet Goethe's observation: "to luxuriate [without effort] makes mean," enjoying knowledge without hard scholarly labors amounts to materialist, "base sensuality of the mind."26 Gnostics sought such pleasant, unscholarly truth without investing existential sacrifice to achieve it. The very opposite is Anselm's grand, overarching program-namely, fides quaerens intellectum - faith seeking understanding.

The encounter of ancient scholarship scientia with Christianity's fides in the first centuries of the first millennium immensely enriched both. In later antiquity an unspent youth met this symbiosis. The youthful Germanic tribes met Christianity in the Church and knew themselves "called to become coheirs of ancient culture and scholarship,"27 as Söhngen pointedly formulated. The Germans studied at the feet of the Christian and pagan masters they so much venerated in order to appropriate their knowledge and wisdom. This resulted in something altogether novel: Scholasticism, a young expression of the European spirit, carrying ancient culture and scholarship over into the Middle Ages.

$24 \quad$ Ibid, 15. See Augustine, De Trinitate XIII, c. 19, no. 24.

25 Söhngen, "Die antik-christliche Wissenschaft," 15.

26 Goethe: "Genießen macht gemein" and Söhngen: "Erkenntnisgenuß ohne wissenschaftliche Arbeit ist gemeine Wollust des Geistes." Söhngen, "Die antik-christliche Wissenschaft und Weisheit in Anselms neuer, germanischer Denkform," 15.

27 Söhngen, "Die antik-christliche Wissenschaft und Weisheit in Anselms neuer, germanischer Denkform," 15. 
As a side note: Söhngen takes exception with the position of the Protestant theologian Hans von Schubert (1859-1931). Schubert, who had authored a book titled tellingly The History of the German Faith in $1924,{ }^{28}$ had therein considered the Middle Ages wholly alien to "the German nature." 29 Against von Schubert, Söhngen asserts that the German Reformation was not "a national" reaction against a medieval worldview wholly foreign to Germans-namely, Scholasticism, but a religious protest. Luther had opposed the Scholastic trust in reason and contrasted it against his emphatic theologia crucis.

Thereupon Söhngen introduces Anselm as the most significant thinker of the eleventh century and as the most independent-minded personality of the Middle Ages to his illustrious audience, the Nazi haute volée of East Prussia. ${ }^{30}$ The Nazis in the audience are informed that Anselm was of Lombardian nobility, having Gundolf as his father and Ermenberga as his mother. Therefore he has a thoroughly Germanic pedigree - much like the great minds Hugh of St. Victor, Albert the Great - often also called "Albert the German," Söhngen points out - Hildegard of Bingen, and Nicholas of Kues as well as the later thinkers Kepler, Schelling, Hegel, Schiller, Hölderlin, and Mörike, so much extolled by Nazi propaganda. All of these Christians had been German. They demonstrate how very congenial the "Deutsche Geist" (the German mindset) is to Christianity and how Germans had brought Christianity and ancient thinking to new and theretofore unprecedented heights. ${ }^{31}$

With this unambiguous introduction Söhngen embarks on discussing the basic outlines of Anselm's proof of God's existence. He detects an extreme degree of profundity and astuteness in the Proslogion. No significant philosophical thinker since, including Descartes, Leibniz, Kant, Hegel, can surpass Anselm's proof. Anselm attempts to prove divine existence from one, stringently conclusive primordial thought ("einen einzigen, beweiskräftigen Urgedanken") requiring no exterior buttress in his judgment..$^{32}$ This primordial thought must be such that the denier of God's existence must be able at least to think it, even when denying His actual existence. In fact, if we think God then at

28 Hans von Schubert, Die Geschichte des deutschen Glaubens (Leipzig: Quelle \& Meyer, 1925).

29 Söhngen, "Die antik-christliche Wissenschaft," 16.

30 Ibid, 16: "Er ist die größte Denkergestalt des XI. Jahrhunderts und, wenn auch nicht der umfassendste, so doch der selbständigste Geist des Mittelalters.“

$31 \quad$ Ibid, 17.

32 Ibid, 18 
Dogmatic Theology

least we think "as that beyond which nothing greater can be thought." This must be both greater than anything imaginable (thinkable) and real. Thought can only be imaginably greatest if it is really the greatest. Unfortunately, Söhngen observes how this thought was frequently misunderstood. Seeing Anselm through the lenses of Leibniz and Kant may be excused as a misunderstanding of Anselm. One hundred Thalers are precisely not "ein Begriff," a concept or term, and, therefore, certainly incomparably different from the term "God" (it is sui generis as term) as Hegel already had pointed out. "Island" or "Thaler" are not words of the same ontic valence as "God." Anselm's superior response to Gaunilo is that, if there is something ontologically greater to be thought than "God," then he will be delighted to give Gaunilo the lost island. ${ }^{33}$ While assuredly the term "God" is the result of faith, it nevertheless is formed and understood by way of reason. As such, it is a mediating term between fides and ratio. It is the achievement of the intellectus fidei. Though this is rendered plausible sola ratione, it becomes luminously clear in faith. ${ }^{34}$

Now Söhngen presents his understanding of Anselm's theological program. For this he turns to the Cur Deus Homo. Theology is insight into faith, or intellectus fidei. Insight to Anselm means using radically reasoned (sola ratione) insight into the necessary reasons. And yet, this does not occur without faith, as it is faith that encourages one to proceed to truth. "Believing in the true God, entails trusting in the power of the [human] spirit according to Anselm ...[,]" being able to hear revelation and to give it human, rational expression. ${ }^{35}$

This brings him to a central Christian dogma, the incarnation. Söhngen characterizes dogma as "überzeitlich;" it transcends temporality. Yet, consonant with the mystery of the Incarnation, it is translated in different ages into the particular idiom of a specific time and people.

Human beings' imagination is bound to images, which also applies to antiquity when the contrast between master and slave was particularly powerful. This is extrapolated unto the cosmic order. This is the background of Paul speaking of pagan deities and the Law. This view is compared to the true Lord and God of creation, offering ransom through crucifixion for human beings enslaved by sin and death. Söhngen paraphrases Augustine to illustrate Anselm's view: as the evil powers of this world assaulted the one who had not fallen victim to their baseness, He, Jesus, broke their power. Jesus is now the "Master,"

\begin{tabular}{ll}
\hline 33 & Ibid, 19. \\
34 & Ibid, 20. \\
35 & Ibid.
\end{tabular}


who liberates His disciples from enslavement to the dark forces of this world. The English word "master" is nota bene "Herr" in German. The Nazis had claimed that Germans are the "Herrenrasse," the master race of the world. This cosmic view offered the ancient world a dramatic interpretation of world history, giving depth to the social order and its attendant ethos that can be righted in Christ. The Gospel reveals that an overarching purpose to history exists, which applies to all people and not just one particular race. Söhngen emphasizes that every human being qua homo is gifted with intellect (Geist). Indeed, Christians provide "the hour of birth to a philosophy of history" ${ }^{36}$ in the sense of fulfilling this search.

With the transition from antiquity to the Middle Ages the Christian understanding of redemption had to develop a different, interpreting image to convey the same, ageless Christian message of atonement, as Söhngen tells his not very captive audience. Otherwise, redemption would become "an abstract and thereby also an empty term," as the local German hero Immanuel Kant had correctly observed in the Critique of Pure Reason ${ }^{37}$ - Kant's town Königsberg (present-day Kaliningrad) is less than 50 miles away from Braunsberg. This is Anselm of Canterbury's signal achievement, and he uses the Germanic understanding of law to bring this about. Anselm introduces the notion of "satisfaction" to explain the Christian mystery of redemption to the Franks, Anglo-Saxons, and other Germanic tribes. By using such a Germanic concept, he introduces a more personal and more spiritual perspective to Christianity than antiquity. According to Söhngen, in antiquity the emphasis had been on sin as a real, but suprapersonal cosmic power, to which humankind had collectively fallen victim. ${ }^{38}$ This impersonal understanding is well captured in the terms "slave to the devil," "original sin," and "concupiscence." Anselm brings to bear a new, supposedly genuinely Germanic perspective of sin as a personal attack against the highest value of a human person: honor. This concept of honor is compared to insult. Sin insults God and His infinite honor, majesty, and holiness. While, there is no gainsaying that such an attack does not harm God in His aseity, the sinner who acts dishonorably vis-à-vis God loses his original honor. The sinner cannot restore his state of honor on his own. Söhngen points out that, in old Germanic law, a "Meintat" (a dishonorable and immunible crime

$36 \quad$ Ibid, 21.

37 Ibid, there referencing Immanuel Kant, Critique of Pure Reason, B 75.

Ibid, $21 \mathrm{f}$. 
Dogmatic Theology which cannot be righted by penance performed by the perpetrator) ${ }^{39}$ is a grievous transgression that requires a satisfaction commensurate 1) to the gravity of the sin and 2) to the greatness of the one insulted. Insult of the infinite God requires a satisfaction of infinite value. Since all human beings are dishonorable in comparison to God and every human being is ontologically inferior, as a finite being, no one less than God Himself must supply satisfaction for His insulted divine honor and, thereby, pursue magnanimously the restoration of human honor. This occurs through the incarnation of Jesus Christ. And thus, Söhngen concludes, "the Godman Jesus Christ supplied vicariously satisfaction for the insulted honor of God, by paying with his infinitely precious life 'Blutund Wergeld,' blood money for the sins of all people." "Anselm expresses this universal restoration using the Latin term "rectitude," or uprightness in English. This term brings about a less forensic understanding of redemption and introduces the more spiritual and personal dimensions of the Christian understanding of redemption.

In a footnote Söhngen elaborates that such "Vergeistigung" (spiritualization) betrays a characteristic feature of the Germanic mindset. It replaces the ancient "Loskauflehre" (i.e., the teaching on the ransom of the sinner from the hands of the devil). The Patristic, impersonal understanding of ransoming the human race is replaced by God freeing the individual person. This is the original Germanic contribution to Christianity. While one might interject that there is a juridical dimension to Anselm teaching of satisfaction, this dimension also applies to Paul's understanding of salvation. In the case of Anselm, however, the new understanding of satisfaction is perceived from his more comprehensive perspective of "rectitude," ${ }^{41}$ a term that captures and

See Jürgen Weitzel, ed, Hoheitliches Strafen in der Spätantike und im frühen Mittelalter (Cologne: Böhlau Verlag, 2002).

Söhngen, "Die antik-christliche Wissenschaft," 22. The word "Wergeld" (known in Old High German as "Weragelt," or "Wergelt," to the Old High German "Wer" "one." See the cognate "Werewolf") was the atonement money in Germanic law. In the case of a manslaughter, the manslayer had to pay compensation to the relatives of the slain, who otherwise would have had to exercise the blood revenge or the feud. Since the acceptance of the "Wergeld" deprived the injured clan of the right to feud, it was one of the important early legal instruments for social peacekeeping in times when a state monopoly on the use of force did not yet exist or could not be enforced. The value money went to the next male relative of the injured party; if these did not exist, it also went to women. "Wergeld" was applied not only to homicide, but also to other offenses. See Andreas Roth, "Wergeld," in Lexikon des Mittelalters, Bd. 8, arr. by Robert Auty (Munich, Stuttgart: Deutscher Taschenbuch Verlag, 2003), rubrics 2199-2201. 
expresses something akin to the personal conformation of the sinner to the moral uprightness or integrity of Christ as the Godman and the Son of Man.

In Anselm's understanding of redemption, this Germanic spiritualization takes on two forms: 1) the modification of the ancient and Augustinian understanding of original sin (this point Söhngen does not further elaborate) and 2) the Christianization of the pagan Germanic understanding of the concepts of "honor" and "satisfaction." Implicitly, he argues that Germanic thinking introduces a personal dimension to soteriology. Just as the ancient notion of a cosmic power weighed heavily on the Mediterranean mind, so also the Germanic notion of blood revenge stifled hope for the old pagan Germanic peoples. Shaming crude National Socialist chauvinism, Söhngen introduces the quintessential German theater piece, Richard Wagner's Nibelungenlied-the "German Iliad"—used so greatly by Nazi propaganda:

At the end of [the German poet Christian Friedrich] Hebbel's [1813- 63] play "Nibelungen" Etzel [King Attila] cedes his crowns to Dietrich von Bern [King of Verona], in order to bring the terrible drama of blood revenge to an end, and Dietrich assumes the reign "in the name of the one who paled on the cross.: Similarly, [by way of] the theory of satisfaction the Germanic thinker Anselm lifts the crown jewel of Germanic juridical thinking to the heights of honor and sets it into the name and crown of victory of the one who paled on the cross. ${ }^{42}$

\section{The Essential Unity of Human Culture and the Christian Faith}

Söhngen reminds his audience that as long as human beings appreciate spirituality and intellectuality - in German "Geistigkeit" people will express appreciation for Anselm's thoughts; the alternative would amount to pagan barbarism he cautions. Anselm's thoughts reflect his ascetism, his spiritual collection, and disciplined thinking - values common to all human beings. In this context Anselm arrives at "the one argument" for the demonstration of God's existence, as his biographer Eadmer so well records. Already Plato in the Phaedo had emphasized the quasi-monastic features of a true philosopher, the definition of which includes one who dies to himself and mortification. The organic continuity of Christian thinking with ancient philosophy, and of Christianity and Germanic life, evidences the remarkable, universal coherence of the human condition. It finds profound expression

$42 \quad$ Ibid, 23. 
Dogmatic Theology

in Anselm's radically inquisitive reason that seeks the all-sustaining and necessary primordial concept and ground. Anselm seeks to comprehend what he believes as a Christian: God as the highest personal good. He seeks to understand, not in order to believe, but rather credo ut intelligam (I believe in order to understand) as the Proslogion famously and programmatically states. Söhngen sees Anselm uniting the undiminished powers of supernatural faith and human reason to one grand, symphonic unity. Such "unbroken power of the intellect (Geist) is the accomplishment of Anselm, a personality possessing the unbroken youthful energy of a Christian and the unspent youthful national (völkisch) energy of the German." ${ }^{43}$

The cosmopolitan Cologne priest Gottlieb Söhngen was talented in navigating different worldviews. Granted, he overstates the Germanic dimension in the monk and thinker Anselm, but he does so Suaviter in modo, fortiter in re, as the Jesuit Claudio Acquaviva (1543-1615) poignantly formulated. Söhngen does not argue against the primitive exaltation of everything ethnically German. But neither does he compromise the Christian statement or Anselm's thought. Instead, he argues that universal Christianity reaches a new climax in the "Germanic" thinker Anselm of Canterbury. To this end, he demonstrates how Anselm uses pagan Germanic terms to enrich the Christian understanding of redemption. In this way, he tries to immunize Christianity from the destructive powers of National Socialism. Söhngen uses the Latin editions of Anselm's writings, and Allers' translation. ${ }^{44}$ Rarely does he refer to the research of Adolf Kolping and Anselm Stolz. ${ }^{45}$ Söhngen argues firmly against dull Nazi materialism. The human being is essentially the unity of spirit, mind, and intellect. Any denial of this ontologically grounded interdependent unity amounts to inhumanism. In addition, Söhngen insists on the inseverable link between antiquity and humanism, between Scripture and Christianity, between early Christendom, the Christian Middle Ages, and the present.

$43 \quad$ Ibid.

44 RudolfAllers, Anselmvon Canterbury. Leben, Lehre und Werke (Vienna:ThomasVerlag, Hegner, 1936).

45 Adolf Kolping, Anselms Proslogion-Beweis der Existenz Gottes, in Grenzfragen zwischen Theologie und Philosophie VIII (Bonn: P. Hanstein, 1939). Anselm Stolz, Anselm von Canterbury (Munich: Kösel-Pustet, 1937). 


\section{Bibliography}

1. Allers, Rudolf. Anselm von Canterbury. Leben, Lehre und Werke. Vienna: Thomas-Verlag, Hegner, 1936.

2. Augustine. De Trinitate.

3. Barth, Karl. Eine Schweizer Stimme, 1938-1945. Zürich: Theologischer Verlag, 1945.

4. Clauss, Manfred. "Die Theologische Hochschule Braunsberg." In, Preussen als Hochschullandschaft im 19./20. Jahrhundert. Edited by Udo Arnold. Lüneburg: Norddeutsches Kulturwerk, 1992.

5. Conway, John S. The Nazi Persecution of the Churches 1933-1945. Vancouver: Regent College Publishing, 2001.

6. Hummel, Karl-Joseph, Michael Kiener, and Christof Morrisey. Catholics and Third Reich: Controversies and Debates. Paderborn: Schöningh-Brill, 2018.

7. Kant Immanuel, Critique of Pure Reason.

8. Klausnitzer,Wolfgang. "Gottlieb Söhngen.” In Biographisch-Bibliographisches Kirchenlexikon (BBKL), Band 21. Nordhausen: Bautz, 2003.

9. Kolping, Adolf. Anselms Proslogion-Beweis der Existenz Gottes, in Grenzfragen zwischen Theologie und Philosophie VIII. Bonn: P. Hanstein, 1939.

10. Korschoke, Martin. Geschichte der bekennenden Kirche, allein das Wort hat's getan. Göttingen: Vandenhoeck \& Ruprecht, 1976.

11. Meindl, Ralf. Ostpreussens Gauleiter: Erich Koch - Eine politische Biographie. Osnabrück: Fibre, 2007.

12. Overy, Richard James. The Dictators: Hitler's Germany and Stalin's Russia. New York: W. W. Norton, 2004.

13. Ratzinger, Joseph. Milestones. Memoirs 1927-1977. San Francisco: Ignatius, 1998.

14. Ratzinger, Joseph. The Theology of History in St. Bonaventure. Translated by Zachary Hayes, OFM. Chicago: Franciscan Herald Press, 1989.

15. Ratzinger, Joseph. "Volk und Haus Gottes in Augustins Lehre von der Kirche: die Dissertation und weitere Studien zu Augustinus und zur Theologie der Kirchenväter." In Joseph Ratzinger, Joseph Ratzinger Gesammelte Schriften, Bd. 1. Freiburg i. Br.: Herder, 2011.

16. Roth, Andreas. "Wegeld." In Lexikon des Mittelalters, Bd. 8. Munich, Stuttgart: Deutscher Taschenbuch Verlag. Arranged by Robert Auty, rubrics 2199-2201. Munich, Stuttgart: Deutscher Taschenbuch Verlag, 2003.

17. Steigmann-Gall, Richard. The Holy Reich. Cambridge: Cambridge University, 2003.

18. Stolz, Anselm. Anselm von Canterbury. Munich: Kösel-Pustet, 1937.

19. Söhngen, Gottlieb. Die katholische Theologie als Wissenschaft und Weisheit. Paderborn: Winfriedbund, 1932.

20. Söhngen, Gottlieb. Sein und Gegenstand. Das scholastische Axiom Ens et Verum convertuntur als Fundament metaphysischer und theologischer Spekulation. Münster: Aschendorff, 1930.

21. Söhngen, Gottlieb. Teilhabe am göttlichen Wissen. Unpublished Habilitation, University of Bonn, 1931. 
22. Söhngen, Gottlieb. Über analytische und synthetische Urteile. Eine historisch-kritische Untersuchung zur Logik des Urteils. Köln: J. Bachem, 1915.

23. Söhngen, Gottlieb. "Credo ut intelligam." In Lexikon für Theologie und Kirche, Second Edition, Bd. 3. Freiburg i. Br.: Herder, 1959.

24. Söhngen, Gottlieb. "Die antik-christliche Wissenschaft und Weisheit in Anselms neuer, germanischer Denkform." In Wissenschaft und Weisheit 8 (1941).

25. Söhngen, Gottlieb. "Die Einheit der Theologie in Anselms Proslogion." In Die Einheit der Theologie. Munich: Karl Zink, 1952.

26. Söhngen, Gottlieb. "Die Weisheit der Theologie durch den Weg der Wissenschaft." Mysterium Salutis, Bd. I. Einsiedeln: Benzinger, 1965.

27. Söhngen, Gottlieb. "Fides quaerens intellectum." In Lexikon für Theologie und Kirche. Second Edition, Bd. 4. Freiburg i. Br.: Herder, 1960.

28. Söhngen, Gottlieb. "Ontologischer Gottesbeweis." In Lexikon für Theologie und Kirche. Second Edition, Bd. 7. Freiburg i. Br.: Herder, 1962.

29. Von Schubert, Hans. Die Geschichte des deutschen Glaubens. Leipzig: Quelle \& Meyer, 1925.

30. Weitzel, Jürgen, ed. Hoheitliches Strafen in der Spätantike und im frühen Mittelalter. Cologne: Böhlau Verlag, 2002. 